\title{
Oman's Trade Potentials with Indian Ocean Rim Countries
}

\author{
Azmat Gani \\ Department of Economics and Finance, College of Economics and \\ Political Science, Sultan Qaboos University, Muscat, Oman \\ azmat@squ.edu.om \\ Haslifah M. Hasim \\ Department of Actuarial Mathematics and Statistics, Heriot-Watt University, \\ Edinburgh, United Kingdom \\ h.hasim@hw.ac.uk \\ Nasser Al-Mawali \\ Ministry of Economy, Muscat, Oman \\ almawali@scp.gov.om
}

\begin{abstract}
Oman's regional trade flow, especially with the Indian Ocean Rim countries, is examined within a gravity model framework. The analysis is based on the generalised method of moments (GMM) estimation procedure. The findings show that Oman's exports are strongly determined by the Indian Ocean Rim countries' populations, gross domestic product, infrastructure, Oman's trade policy and a common border and language. Distance is found to induce significant friction for Oman's imports. We conclude that the Indian Ocean Rim countries are sources of active markets and provide opportunities for greater trade integration. In light of the dramatic decline in world oil prices in recent years, Oman also needs to reduce its reliance on oil earnings and intervene more aggressively in its domestic economy by diversifying its non-oil sector and concentrate more on non-oil led exports.
\end{abstract}

\section{Keywords}

Oman - Indian Ocean - trade - imports - distance

(C) AZMAT GANI, HASLIFAH M. HASIM AND NASSER AL-MAWALI, 2020 | DOI:10.1163/15691497-12341574 
Oman is one of the emerging markets in the Middle East and the North African (MENA) region that has recorded impressive economic growth. Its real gross domestic product (GDP) grew at an annual average rate of 3.3 per cent between 2000 and 2019, attributable primarily to high crude oil prices and sustained domestic demand. The share of petroleum activities in the overall GDP of Oman amounted to 36 per cent in 2018, with oil and gas contributing about 78 per cent of the total government revenues in 2018 (Central Bank of Oman, 2019). The non-petroleum sector added 68 per cent of the GDP in 2018. Income from commodity exports has been primary sources of income for Oman and other neighboring countries. While modern agriculture has contributed to reductions in food-energy-water poverty (Ozturk, 2017), it has also facilitated many countries' integration into the global capitalist economy, as noted by Joseph (2018) in the case of the United Arab Emirates. However, Oman's integration has been primarily supported by its oil exports. Recent developments in the international markets, particularly in commodity prices, are of growing concern to commodity exporters like Oman. The country is bracing for some tough times ahead as vital oil revenues plunge as a result of a sharp fall in world oil demand propelled by the coronavirus (CoviD-19) pandemic. While Oman's crude oil fetched US\$103.oo per barrel in 2011 (Central Bank of Oman, 2012), the world oil prices recently dropped by more than half from their peak of US\$115.0o per barrel in June 2014 to around US\$40.00 per barrel in early October 2020. The low oil prices together with CoviD-19 induced disruption to economic activities is unleashing a devastating effect on Oman's economy.

Oman's economy is in transition, with the Government's emphasis being on economic diversification and engagement with greater global integration regarding trade, cultural exchange and international relations. One significant development that has been taking place in the domestic economy is the pursuit of an economic policy that aims to liberalize and diversify the local production base (World Bank, 2010) to create the right conditions for and a closer match with the underlying principles of greater global trade integration. As part of its drive towards greater economic integration and to realize the benefits of trade, Oman joined the World Trade Organisation (wто), with its membership confirmed in 2000. Historically, however, Oman has maintained a friendly working and cultural relationship with several countries within the major regions of the Middle East, Africa and Asia for decades.

Countries throughout the world intend to expand their trade structure to achieve higher integration and participation in the global trading environment to obtain higher levels of economic growth. Trade has fostered financial 
transfers between regions and equalized incomes (Gumpert, 2019), allowed economic development (Le and Tran-Nam, 2018) and raised productivity levels (Broda, Greenfield, Weinstein, 2017). The economy-wide effects of trade have been addressed comprehensively in the theoretical and the empirical literature, for example, Al-Marhubi (2000 and 2005); Thennakoon and Dissanayake (2015), Keho (2017), and Philbin (2017). Irshad et al. (2018) provide a comprehensive review of the beneficial effects of trade within a gravity modelling framework. However, literature has also revealed the downside effects of trade. For example, Irandoust (2018) noted that globalisation increased militarization. Feng et al. (2018) observed that countries with a common border showed evidence of corruption due to the transfer of illegal goods. Hye et al. (2014) in their study found trade liberalization to be negatively associated with economic growth. On balance, the findings from several empirical studies give enough confirmation that international trade is welfare enhancing.

Many of the gains from countries opening up to international trade extend beyond the necessary exchange of much-needed goods and services to accessing the trading partners' technological know-how, more significant market share, and more research and development; obtaining investment funds and intermediate products; strengthening political and international diplomatic relations; and reinforcing institutions. Openness to trade also improves good governance as well as having environmental implications. For example, Ozturk, Al-Mulali and Saboori (2016) have found that trade openness matters for ecological footprint, while Al-Marhubi (2004) observed that openness to trade, among other factors, have a significant impact on governance.

As part of its effort to access the broader trading market and its desire to integrate with the larger world economy (Gani and Al-Mawali, 2013), Oman also took the initiative to become a member of the regional bloc: the Indian Ocean Rim Association for Regional Cooperation (IOR-ARC) group of countries in March 1995 (see Section 2 for further discussion). This initiative was to increase its levels of trade, investment and tourism while maintaining its traditional historical and cultural values. Theoretically, the IOR-ARC has been considered as a node for Oman's regional business flows. Regional trade facilitates more foreign investment, which is essential for growth, as shown by Omri and Kahouli (2014) in their study on the Middle East and North African (MENA) countries and Gui-Diby (2014) in his study on African countries. Regional trade does positively contribute to economic growth (Bayar and Gavriletea, 2017). The countries of the IOR-ARC group have also contributed positively to Oman's economic welfare. At the same time, IOR-ARC is likely to have benefitted through Oman's secure energy supplies as Furtig (2010) has noted in the case of the European Union and the Gulf Co-operation Council countries. To 
facilitate its aim of broader integration, Oman also took the initiative to liberalise its trading environment, which is now considered to be a more liberal and fast-growing economy.

Oman seized the opportunity of a decade of high oil prices to build its economy outside the oil sector. Although the pace of the diversification of the non-oil industry has been slightly slower than expected, the Omani economy is undoubtedly more diversified now than it was a decade ago. For example, the Wто (2008) noted that, if preferences are taken into account, then Oman's trade regime is a little more liberal, since the simple average of the applied tariff is $5.2 \%$. Also, the domestic economic environment is more competitive, and according to The Global Competitive Report 2019 (World Economic Forum), Oman's global competitive ranking was 53 out of the 144 countries assessed in 2018. Concerning the ease of doing business, Oman was ranked thirty-two out of 190 countries in 2019 (World Bank, 2020), compared with fifty-first out of 155 countries in 2006 (World Bank, 2012). These indications confirm that Oman is firmly committed to the principles of domestic economic reforms, paving the way to a more open, competitive economy. As a sign of its commitment, major infrastructural investment projects are being undertaken to support the private sector and improve the business environment as well as allowing the growth of the non-oil industry, such as tourism and retail services.

The IOR-ARC offers the potential for more trade and investment opportunities for Oman in light of its investments in the non-oil sector and infrastructure and its ongoing economic reforms in the business environment. Oman is also turning more towards bilateral free trade agreements as a result of the developments following the global financial crisis to extend its trade reach, exploring investment opportunities as well as minimizing the risks of the weakening of the international markets. More significant trade can also foster peace (Rabi and Mueller, 2017). It is quite likely that countries around the globe will engage in more bilateral and regional cooperation initiatives, and their proliferation is already noticeable in regions such as Asia and Africa. Pike et al. (2017) have argued that regional development is a global challenge as a result of the acceleration of the globalisation and transformation in geopolitical order. From this line of thinking, Oman's engagement with the IOR-ARC is recognized as a path towards regional integration and development. For example, Sen (2006) argued that, since the regional financial crisis of 1997-1998, there had been an ongoing phenomenon of the proliferation of bilateral and regional trading agreements in the Asia-Pacific region. Similar sentiments also are expressed in a recent study by Crescenzi and Iammarino (2017). These scholars argue that the intensification of global economic integration has spurred the need to place regional development in a genuinely open and interdependent framework. 
Oman's long-term growth prospects will be dictated by the growth of its non-oil sector and closer export markets. Recent developments in the world economy, such as the threat of Covid-19, USA's trade war with China, the possibility of the exit of the United Kingdom from the European Union (вREXIт), and a fall in oil prices pose significant economic challenges for many countries. Oman is no exception to these threats, and in particular, with a subdued outlook for the oil prices, it is imperative for Oman to improve the pace of trade integration into the international trading system and secure more markets for its non-oil sector. Given these potential threats, this study aims to investigate the factors explaining Oman's trade flows with the IOR-ARC countries. In the light of Oman's efforts to liberalise its trade sector and adopt more extensive economic reform initiatives, there is a strong likelihood that its trade will increase, with more and newer entrants appearing on its list of trading partners. This study is crucial for assessing Oman's potential for future free trade as well as formalizing bilateral trade relations with more and more countries within its regional perimeters. This analysis will add value in terms of supporting government policymakers in formulating more targeted regional trade policies. To the best of our knowledge, this is the first study to examine Oman's trade with the IOR-ARC group of countries, and it makes a new contribution to the research and literature involving the IOR-ARC group of countries.

The structure of this paper is as follows: Section 2 discusses some aspects of trade with the IOR-ARC countries. Section 3 presents the analytical framework and discusses the empirical findings, while Section 4 gives a robustness check to ensure the model's validity - a conclusion to the paper is provided in Section 5 .

The IOR-ARC group of countries came into effect on 29-31 March 1995, when the Government of Mauritius convened a meeting to discuss the enhancement of economic cooperation among the nations of the Indian Ocean Rim. The IOR-ARC now comprises twenty countries as full members, which includes Australia, Bangladesh, Comoros, India, Indonesia, Iran, Kenya, Madagascar, Malaysia, Mauritius, Mozambique, Oman, Seychelles, Singapore, South Africa, Sri Lanka, Tanzania, Thailand, the United Arab Emirates (UAE) and Yemen. Also, six countries are dialogue partners, and these include China, Egypt, France, Japan, the United Kingdom (UK) and the United States of America (USA). The IOR-ARC is now a regional forum, tripartite in nature, which brings together representatives of the governments, business and academia 
in promoting regional cooperation. Its core guiding principle is open regionalism for strengthening economic cooperation, particularly concerning trade facilitation and investment promotion as well as the social development of the member countries. It operates on four main working principles: (1) open regionalism, (2) the basis of cooperation, (3) volunteerism, and (4) consensus.

Oman's membership to the IOR-ARC is undoubtedly a reliable indicator of its desire to integrate with a broader region that has the potential to offer opportunities for a significant export market. Regional cooperation has been an agenda item for trade policy discussions in Oman as well as with its nonIOR-ARC trading partners. Oman, like other countries, is aggressively pursuing regional trade relationships following the 2007 global financial crisis. Countries elsewhere also took a similar stance. For example, according to Brooks and Ferrarini (2011), bilateral and regional cooperation initiatives involving Asian economies have proliferated in the last two decades. It is noteworthy that two of the largest developing economies, China and India, are undergoing a similar process of engaging in regional trade agreements (Gani and Ahmad, 2020). Following the regional financial crisis of 1997-1998, there has been an ongoing phenomenon of the proliferation of bilateral and regional trading agreements in the Asia-Pacific region (Sen, 2006 and Gani and Scrimgeour, 2016). According to Snyder (2009), China has economic integration agreements with other countries in Asia as well as with non-Asian countries. India, one of the other large Asian economies, has also engaged in more comprehensive regional trading agreements with its neighbouring countries, including some of the significant Organisation for Economic Cooperation and Development (OECD) economies (Seshadri, 2009).

Concerning the Arab countries, economic integration regarding trade in goods as well as services, labor, and capital had been a critical economic policy for several years. Greater economic and monetary integration is a long-term objective of the Gulf Cooperation Council (GCC) member states that dates back several years to the Economic Agreement of 1981. Tas and Togay (2012) noted that the GCC member countries integrated at many levels following the establishment of a customs union in 2003. Although the achievements towards more significant economic and monetary integration vary from one GCC member state to another, there are signs that some progress has been made in some countries, particularly regarding greater economic integration (but not monetary integration) within GCC member states in recent times. Oman's involvement in the integration process is not new, as noted by the studies mentioned above, and its desire for greater regional integration and market access - i.e., its membership in the IOR-ARC - is another positive development regarding working towards greater regionalism. 
Although Oman has actively traded with a number of the IOR-ARC countries since its membership, its share of trade is low with many of the states (Table 5.1). Oman's major export commodity is petroleum and petroleum products, as a result of its economic diversification initiatives, it also exports a range of non-oil products to the IOR-ARC countries and elsewhere. Among

TABLE 5.1 Oman's exports to and imports from the IOR-ARC countries in 2016

\begin{tabular}{|c|c|c|}
\hline $\begin{array}{l}\text { IOR-ARC } \\
\text { member countries }\end{array}$ & $\begin{array}{l}\text { Export partner share } \\
\text { (per cent) }\end{array}$ & $\begin{array}{l}\text { Import partner share } \\
\text { (per cent) }\end{array}$ \\
\hline Australia & 0.11 & 0.78 \\
\hline Bangladesh & 0.20 & 0.01 \\
\hline Comoros & 0.00 & 0.00 \\
\hline India & 3.78 & 4.82 \\
\hline Indonesia & 0.16 & $0.5^{1}$ \\
\hline Iran & 0.92 & 2.76 \\
\hline Kenya & 0.38 & 0.06 \\
\hline Madagascar & 0.06 & 0.00 \\
\hline Malaysia & 1.04 & 0.69 \\
\hline Mauritius & 0.02 & 0.00 \\
\hline Mozambique & 0.23 & 0.00 \\
\hline Seychelles & 0.01 & 0.00 \\
\hline Singapore & 1.13 & 1.53 \\
\hline South Africa & 1.26 & 0.05 \\
\hline Sri Lanka & 0.14 & 0.08 \\
\hline Tanzania & 0.16 & 0.08 \\
\hline Thailand & 0.20 & 0.43 \\
\hline UAE & $7 \cdot 53$ & 45.06 \\
\hline Yemen & 2.12 & 1.26 \\
\hline \multicolumn{3}{|c|}{ IOR-ARC Dialogue Partners } \\
\hline China & 43.61 & 4.84 \\
\hline Egypt & 0.18 & 0.54 \\
\hline France & 0.51 & 0.79 \\
\hline Japan & 2.49 & 2.18 \\
\hline UK & 0.15 & 1.47 \\
\hline USA & $3 \cdot 32$ & $3 \cdot 30$ \\
\hline
\end{tabular}

SOURCE: WORLD INTEGRATED TRADE SOLUTION (WITS) AVAILABLE: HTTPS://WITS .WORLDBANK.ORG 
the IOR-ARC countries, India, Singapore, and Thailand are its most significant oil buyers, while among the IOR-ARC dialogue partners, China, Japan, and the USA are significant buyers of Oman's oil. Oman's non-oil export destinations also include some IOR-ARC countries. Oman's non-oil export markets are wide and varied, with South Africa, the UAE, Kenya, and India being the main destinations. Oman's sources of imports confined mainly to the UAE and India among the IOR-ARC countries. According to the Central Bank of Oman (2011), in $2010,58 \%$ of Oman's total exports went to Asia, $4 \%$ to America, $1 \%$ to Europe and the remaining $37 \%$ to other countries.

The IOR-ARC countries are undoubtedly crucial to Oman, with some countries standing out as essential trade destinations. Figures 5.1 and 5.2 depict Oman's exports and imports as a percentage of the total for the significant IOR-ARC trading partners. As shown in Figure 5.1, India ranks as the top import partner, followed by the UAE. Two striking patterns are evident from Figure 5.2: imports from the UAE declined significantly between 2000 and 2010, while imports from India increased quite sharply during the same period. The imports from all other countries remained almost the same between 2000 and 2010.

Oman's exports to the main IOR-ARC countries also reveal some interesting patterns. For example, Oman's exports to the UAE rose quite sharply between 2005 and 2009, while its exports to India declined significantly over the same period. Oman's exports to Australia also dipped slightly, while its exports to Asian countries, particularly Malaysia and Thailand, experienced slight increases (see Figure 5.2). Oman's trade relationship with the IOR-ARC countries has shown some signs of strengthening, particularly regarding its exports, as since 2007 its exports to several of the states depicted in Figure 5.2 have experienced some increases.

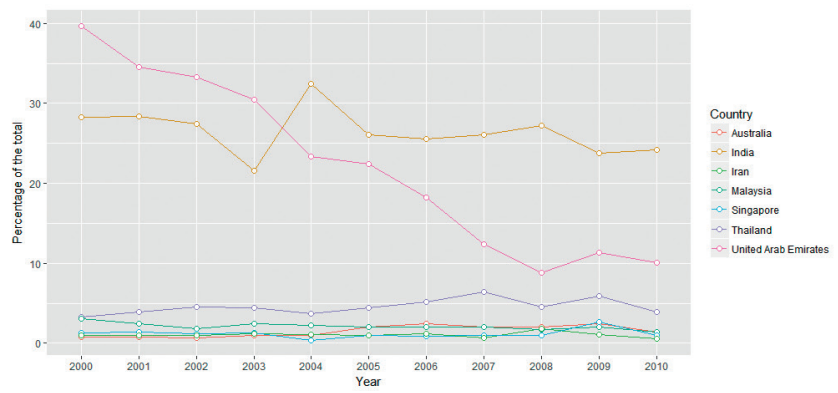

FIGURE 5.1 Oman's imports (percentage of the total) from the main IOR-ARC destinations

SOURCE: UNITED NATIONS COMTRADE DATABASE 


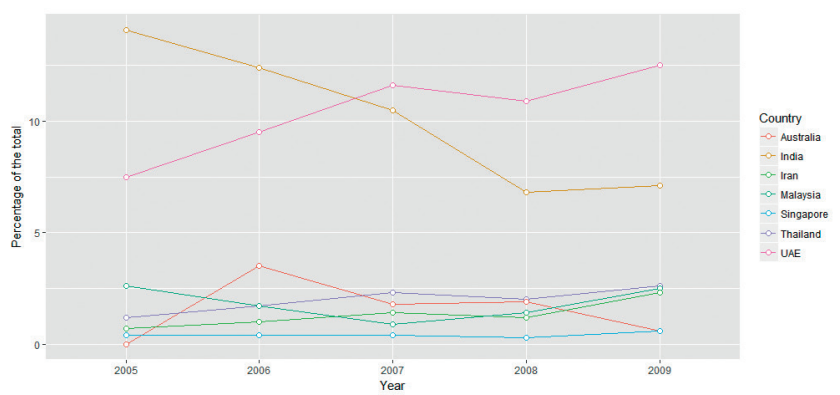

FIGURE 5.2 Oman's exports (percentage of the total) to the main IOR-ARC destinations

SOURCE: UNITED NATIONS COMTRADE DATABASE

While Figures 5.1 and 5.2 depict the current status of Oman's trade with the IOR-ARC countries, an important issue as part of this trade is to examine the commodities traded. Table 5.2 presents data on the imports and exports of significant products sold based on the Harmonised System. Regarding exports, fuels (petroleum oils and crude) form an essential export commodity, contributing just over $63 \%$ of Oman's export shares. Much of Oman's foreign income comes from petroleum and petroleum products, given Oman's natural advantage in oil reserves. Concerning imports, consumer, intermediate and capital goods form the most significant three import components. Machines and electrical equipment contribute some 21 per cent of total import share. A significant amount of imports is made of motor vehicles as a result of increasing incomes. Ozturk and Arisoy (2016) provide evidence of rising incomes fostering consumption of oil-based equipment such as cars, consistent with consumption patterns in Oman. As shown in Table 5.2, many of Oman's commodity imports other than the imports of motor cars consist of items needed for industrial development, such as heavy machinery, fittings and parts.

\section{Identifying the Oman-IOR-ARC Trade Determinants}

The gravity model is considered to be an appropriate framework for understanding the determinants of trade, as shown in Irshad et al. (2018). Theoretically, the primary form of the gravity model relates bilateral trade to the economic mass of the two economies - i.e., Oman and the IOR-ARC - and the distance between them, generally augmented by other possible influences, such as the exchange rate and infrastructure. An essential component of the 
TABLE 5.2 Oman's main export and import products in 2016

\begin{tabular}{lcc} 
Product Group & Export Product Share (\%) & Import Product Share (\%) \\
\hline All Products & 100 & 100 \\
Capital goods & 2.27 & 21.82 \\
Consumer goods & 16.59 & 33.97 \\
Intermediate goods & 15.08 & 25.23 \\
Raw materials & 55.99 & 7.73 \\
Animal & 2.44 & 4.91 \\
Chemicals & 6.44 & 7.52 \\
Food Products & 1.65 & 5.04 \\
Footwear & 0.03 & 0.36 \\
Fuels & 63.36 & 8.68 \\
Hides and Skins & 0.01 & 0.14 \\
Mach and Elec & 2.99 & 20.87 \\
Metals & 5.71 & 12.98 \\
Minerals & 1.36 & 3.62 \\
Miscellaneous & 10.46 & 14.9 \\
Plastic or Rubber & 1.64 & 4.08 \\
Stone and Glass & 1.23 & 5.95 \\
Textiles and Clothing & 0.12 & 1.54 \\
Transportation & 0.65 & 1.6 \\
Vegetable & 1.63 & 5.72 \\
Wood & 0.28 & 2.09
\end{tabular}

SOURCE: WORLD INTEGRATED TRADE SOLUTION (WITS) AVAILABLE: HTTPS://WITS .WORLDBANK.ORG

gravity model is the influence of distance on trade flows, and many researchers have paid attention to the crucial role of distance in determining trade across different boundaries - for example, Deardorff (1995 and 1998), Anderson and van Wincoop (2003), Gibson (2007) and Egger (2008).

Applications of the gravity model are wide and varied, with a diversified country and product categories of trade. Empirical research on trade has generally tended to support the use of the gravity model to analyze trade flows. Several theoretical studies have supported the use of the gravity model with an increasing level of appeal - for example, Anderson (1979); Bergstrand (1985); Helpman (1987); Deardoff (1995) Egger (2000); Anderson and Wincoop (2003); 
and Martinez-Zarzoso (2003). A review of the empirical literature making use of the gravity model shows that the gravity model could continue to explain bilateral trade with reasonable strength in both low and high-income countries (Brun, Guillaumont, de Melo, 2005; Egger, 2008; Liu, Whalley and Xin, 2010; Tebaldi, 2011; Boxell, 2015; and Brodzicki and Uminski (2018). A review of some of the developments in the use of gravity models is provided by Martinez-Zarzozo (2003) and more recently in Irshad et al. (2018).

The general gravity equation takes the form expressed in equation (1).

$$
T_{i j}=\frac{s_{i}^{\alpha} s_{j}^{\beta}}{D_{i j}^{\theta}}
$$

Where $T_{i j}$ is the trade flow from origin $i$ to destination $j ; S_{i}$ and $S_{j}$ are the relevant economic sizes of two locations; $D_{i j}$ is the distance between the trading partners (usually measured from port to port). $D$ acts as a sort of tax wedge that imposes trade costs and perhaps lowers trade flows.

Following the above standard specification of the gravity model, the general form of the Oman-IOR-ARC bilateral trade $(B T)$ relationship can be formulated within the gravity model framework as expressed in Eq. (2).

$$
{ }_{B T_{t}}{ }^{O m a n-I O R}=f\left({ }_{G D P} P_{t}^{O m a n}{ }_{G D P_{t}}^{I O R}\right)^{\phi},\left(\text { POP }_{t}{ }^{O m a n}{ }_{P O P}{ }_{t}^{I O R}\right)^{\xi},{ }_{D I S}{ }_{t}{ }^{O m a n-I O R \psi}, \varepsilon_{t}^{O m a n-I O R}
$$

where, $G D P^{O m a n}$ is the nominal GDP in Oman; $G D P^{I O R}$ is the nominal GDP in the Indian Ocean Rim countries; $P O P O$ Oman is the population in Oman; $P O P I O R$ is the population in the Indian Ocean Rim countries; DIS ${ }^{\text {Oman-IOR }}$ is the geographical distance between Oman and the principal port of entry of an Indian Ocean Rim country; $\varepsilon$ is the error term with the usual properties; and $t$ is the time.

We expand Eq. (2) to include other potential influences on trade between Oman and the IOR-ARC. We cover the bilateral real exchange rate $(R E R)$, for example, Brun, Guillaumont and de Melo, (2005) and Baek (2014); the level of infrastructure development (ID); the trade policy $(T P)$; a common border $(C B)$; and a common language $(C L)$ to minimise model miss-specification as these variables are considered to be instrumental in influencing the level of trade, hence Eq. (3),

$$
\begin{aligned}
& { }_{B T_{t}}^{\text {Oman-IOR }}=f\left(G_{t}{ }^{\text {Oman }}{ }_{G D P_{t}^{I O R}}\right)^{\phi},\left(\text { POP }_{t}{ }^{\text {Oman }}{ }_{P O P}{ }_{t}^{I O R}\right)^{\xi}, D_{t}{ }_{t}^{\text {Oman-IOR } \psi} \text {, }
\end{aligned}
$$

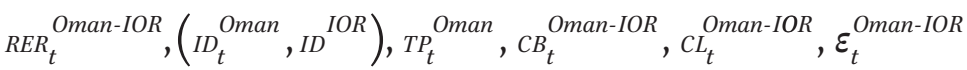


While the IOR-ARC membership consists of twenty countries, our choice of sample countries is limited to those with which Oman engages in trade and for which published data on the variables entering Eq. (3) are available. Thus, the sample of the IOR-ARC countries considered as part of the empirical analysis contains Australia, India, Iran, Malaysia, Singapore, Thailand, and the UAE. Regarding Oman's exports to the IOR-ARC countries, the percentage of exports in total is less than four in most of the nations, and published export data are available for all of the states except Australia. Given this limitation in the export data for Australia, the Oman-IOR-ARC export model includes all of the above countries except Australia. The data are annual for the years 2000 to 2009 for the export model and 2000 to 2010 for the import model. The variable measures and sources of data are summarized in Table 5.3.

Our data are pooled and involve seven countries and eleven-time periods for the import model, constituting seventy-seven observations, and six states and ten-time periods for the export model, forming sixty observations. The regression equation is estimated, taking into account the auto-correlated errors within the cross-sections - i.e., the $\operatorname{AR}(1)$ errors. The panel corrected standard errors method of estimation is adopted. The empirical results obtained from estimating Eq. (3) are reported in Tables 5.4 and 5.5. The $t$-statistics are in parentheses. Many variables produce consistent effects as the right-handside variables successively added to the export and the import equations. In Tables (5.4) and (5.5), specification (1) shows the results of the effects of Oman's population and GDP per capita together with the measure of the real exchange rate and distance, while specification (2) includes two additional variables, a test to capture the trade policy effect and a measure to capture the infrastructure development. The same estimation is for the IOR-ARC countries in specifications (3) and (4). In specification (5), the results of the complete model are presented, and the discussion below is primarily based on these.

Regarding Oman's exports to the IOR-ARC countries, our findings reveal that the coefficients of Oman's population (POP-OMAN) and GDP (GDPOMAM) have negative signs in the complete model (specification 5 ) but are statistically insignificant (Table 5.4). However, we find that the coefficients of the population (POP-IOR-ARC) and GDP of the IOR-ARC countries (GDP-IOR-ARC) have the expected positive signs and are statistically significant at the $1 \%$ level (specifications 2, 4 and 5, in Table 5.4). These findings suggest that Oman's exports are strongly influenced by its IOR-ARC trading partner's population and GDP.

Regarding Oman's imports from the IOR-ARC countries, our findings reveal that the coefficients of Oman's population (POPOMAN) and GDP (GDPOMAN) have the expected signs, being positive and statistically significant at the $1 \%$ 
TABLE 5.3 Variable measures and data sources

\begin{tabular}{|c|c|c|}
\hline Variable & Measure & Source \\
\hline EXPORT & $\begin{array}{l}\text { Oman's total exports to an IOR-ARC } \\
\text { country in US dollars. }\end{array}$ & UN Comtrade \\
\hline IMPORT & $\begin{array}{l}\text { Oman's total imports from an IOR-ARC } \\
\text { country in US dollars. }\end{array}$ & UN Comtrade \\
\hline$G D P^{O M A N}$ & $\begin{array}{l}\text { Gross domestic product per capita for } \\
\text { Oman (constant } 2005 \text { US dollars). }\end{array}$ & World Bank (2019) \\
\hline$G D P^{I O R-A R C}$ & $\begin{array}{l}\text { Gross domestic product per capita for } \\
\text { an IOR-ARC country (constant } 2005 \text { US } \\
\text { dollars). }\end{array}$ & World Bank (2019) \\
\hline POP OMAN & The total population of Oman. & World Bank (2019) \\
\hline POPIOR-ARC & $\begin{array}{l}\text { The total population of each of the } \\
\text { IOR-ARC countries. }\end{array}$ & World Bank (2019) \\
\hline DIS & $\begin{array}{l}\text { The distance between Oman's main port } \\
\text { of entry, Muscat, and the main port of } \\
\text { entry in an IOR-ARC. These include Perth, } \\
\text { Bombay, Dubai, Bangkok, Singapore, } \\
\text { Penang and Bandar Abbas. }\end{array}$ & $\begin{array}{l}\text { Available online at http:// } \\
\text { www.searates.com/ } \\
\text { reference/portdistance } \\
\text { Date of extraction: } \\
17 \text { December } 2014\end{array}$ \\
\hline$T P^{O M A N}$ & $\begin{array}{l}\text { Trade policy, measured by the percentage } \\
\text { tariff rates in Oman (weighted mean, all } \\
\text { products). }\end{array}$ & World Bank (2019) \\
\hline$R E R$ & $\begin{array}{l}\text { Real exchange rate (home country } \\
\text { currency / US dollars). }\end{array}$ & World Bank (2019) \\
\hline$I D$ & $\begin{array}{l}\text { Infrastructure, measured by telephone } \\
\text { mainlines per } 100 \text { people. }\end{array}$ & World Bank (2019) \\
\hline$C B$ & $\begin{array}{l}\text { Common border, measured by a dummy } \\
\text { variable taking a value of } 1 \text { for the shared } \\
\text { border with Oman and o otherwise. }\end{array}$ & Authors \\
\hline$C L$ & $\begin{array}{l}\text { Common language, measured by a dummy } \\
\text { variable taking a value of } 1 \text { for a common } \\
\text { language with Oman and o otherwise. }\end{array}$ & Authors \\
\hline
\end{tabular}


TABLE 5.4 The empirical result of the Oman-IOR-ARC export model

\section{Regression Specifications}

\begin{tabular}{|c|c|c|c|c|c|}
\hline Variables & 1 & 2 & 3 & 4 & 5 \\
\hline CONSTANT & $\begin{array}{l}-41.046 \\
(0.621)\end{array}$ & $\begin{array}{l}-90.083 \\
(4.015)^{*}\end{array}$ & $\begin{array}{c}-60.983 \\
(0.353)\end{array}$ & $\begin{array}{l}-116.16 \\
(3.16 o)^{*}\end{array}$ & $\begin{array}{l}27.991 \\
(0.194)\end{array}$ \\
\hline $\log (R E R)$ & $\begin{array}{l}-1.397 \\
(1.538)\end{array}$ & $\begin{array}{l}0.502 \\
(0.309)\end{array}$ & $\begin{array}{l}-1.595 \\
(1.023)\end{array}$ & $\begin{array}{l}-0.679 \\
(0.433)\end{array}$ & $\begin{array}{l}-1.371 \\
(0.923)\end{array}$ \\
\hline $\log \left(P O P_{-} O M A N\right)$ & $\begin{array}{l}-0.65^{2} \\
(8.892)^{*}\end{array}$ & $\ldots$ & $\begin{array}{l}2.533 \\
(0.174)\end{array}$ & $\ldots$ & $\begin{array}{l}-11.198 \\
(0.941)\end{array}$ \\
\hline $\log \left(G D P_{-} O M A N\right)$ & $\begin{array}{l}6.057 \\
(6.8 \circ 8)^{*}\end{array}$ & $\ldots$ & $\begin{array}{l}3.254 \\
(0.436)\end{array}$ & $\cdots$ & $\begin{array}{l}-1.77^{2} \\
\left(0.35^{8}\right)\end{array}$ \\
\hline $\log \left(I D^{-} O M A N\right)$ & $\ldots$ & $\ldots$ & $\begin{array}{l}0.206 \\
(0.288)\end{array}$ & $\cdots$ & $\begin{array}{l}0.714 \\
(1.230)\end{array}$ \\
\hline $\log \left(T P_{-} O M A N\right)$ & $\ldots$ & $\ldots$ & $\begin{array}{l}1.171 \\
(0.487)\end{array}$ & $\begin{array}{l}3.542 \\
(1.786)^{* * *}\end{array}$ & $\begin{array}{l}3.65^{\circ} \\
(1.883)^{* * *}\end{array}$ \\
\hline $\log (D I S)$ & $\begin{array}{l}0.286 \\
(1.366)\end{array}$ & $\begin{array}{l}3.066 \\
(5.907)^{*}\end{array}$ & $\begin{array}{l}0.282 \\
(1.354)\end{array}$ & $\begin{array}{l}3 \cdot 319 \\
(4.461)^{*}\end{array}$ & $\begin{array}{l}4.008 \\
(4.545)^{*}\end{array}$ \\
\hline$C B$ & $\begin{array}{l}1.485 \\
(4.120)^{*}\end{array}$ & $\begin{array}{l}2.019 \\
(5.412)^{*}\end{array}$ & $\begin{array}{l}1.485 \\
(4.099)^{*}\end{array}$ & $\begin{array}{l}1.629 \\
(3.776)^{*}\end{array}$ & $\begin{array}{l}1.255 \\
(2.242)^{* *}\end{array}$ \\
\hline$C L$ & $\begin{array}{l}\text { o.696 } \\
(1.307)\end{array}$ & $\begin{array}{l}6.197 \\
(6.045)^{*}\end{array}$ & $\begin{array}{l}\text { o.688 } \\
(1.299)\end{array}$ & $\begin{array}{l}7.181 \\
(4.854)^{*}\end{array}$ & $\begin{array}{l}8.691 \\
(4.592)^{*}\end{array}$ \\
\hline $\log \left(P O P_{-} I O R-A R C\right)$ & $\cdots$ & $\begin{array}{l}2.338 \\
(4.590)^{*}\end{array}$ & $\ldots$ & $\begin{array}{l}3.222 \\
(3.560)^{*}\end{array}$ & $\begin{array}{l}4 \cdot 329 \\
(3 \cdot 743)^{*}\end{array}$ \\
\hline $\log \left(G D_{-} P_{-} O R-A R C\right)$ & $\ldots$ & $\begin{array}{l}2.865 \\
(3.714)^{*}\end{array}$ & $\ldots$ & $\begin{array}{l}3.676 \\
(2.822)^{*}\end{array}$ & $\begin{array}{l}5.149 \\
(3.284)^{*}\end{array}$ \\
\hline $\log \left(I D^{-} I O R-A R C\right)$ & $\ldots$ & $\ldots$ & $\ldots$ & $\begin{array}{l}\text { o.639 } \\
(2.436)^{* *}\end{array}$ & $\begin{array}{l}0.898 \\
(2.530)^{* *}\end{array}$ \\
\hline$N$ & 60 & 60 & 60 & 60 & 60 \\
\hline F-statistics & $3 \cdot 5^{1}$ & 5.61 & 2.64 & 5.14 & $3 \cdot 740$ \\
\hline Buse $R^{2}$ & 0.28 & 0.39 & 0.29 & 0.45 & 0.46 \\
\hline
\end{tabular}

Note: * ** and *** indicate statistical significance the: $1 \%, 5 \%$, and $10 \%$ levels respectively. The values in the parentheses are the t-statistics. (...) indicates variable not estimated. 
TABLE 5.5 The empirical result of the Oman IOR-ARC import model

\section{Regression Specifications}

\begin{tabular}{|c|c|c|c|c|c|}
\hline Variables & 1 & 2 & 3 & 4 & 5 \\
\hline CONSTANT & $\begin{array}{l}-70.245 \\
(5.721)^{*}\end{array}$ & $\begin{array}{l}-23.860 \\
(6.600)^{*}\end{array}$ & $\begin{array}{l}-142.99 \\
(4.488)^{*}\end{array}$ & $\begin{array}{l}-11.233 \\
(1.975)^{* *}\end{array}$ & $\begin{array}{l}-148.790 \\
(5.681)^{*}\end{array}$ \\
\hline $\log (R E R)$ & $\begin{array}{l}-1.969 \\
(5 \cdot 370)^{*}\end{array}$ & $\begin{array}{l}-0.169 \\
(0.315)\end{array}$ & $\begin{array}{l}-1.815 \\
(5.298)^{*}\end{array}$ & $\begin{array}{l}-0.674 \\
(1.504)\end{array}$ & $\begin{array}{l}-1.020 \\
(2.870)^{*}\end{array}$ \\
\hline $\log \left(P O P_{-} O M A N\right)$ & $\begin{array}{l}3.269 \\
(1.846)^{* * *}\end{array}$ & $\cdots$ & $\begin{array}{l}7.308 \\
(3.117)^{*}\end{array}$ & $\cdots$ & $\begin{array}{l}6.157 \\
(2.889)^{*}\end{array}$ \\
\hline $\log \left(G D P_{-} O M A N\right)$ & $\begin{array}{l}4.279 \\
(2.872)^{*}\end{array}$ & $\ldots$ & $\begin{array}{l}5.632 \\
(3.694)^{*}\end{array}$ & $\ldots$ & $\begin{array}{l}5.284 \\
(3.850)^{*}\end{array}$ \\
\hline $\log \left(I D_{-} O M A N\right)$ & $\cdots$ & $\ldots$ & $\begin{array}{l}-0.473 \\
(2.368)^{* *}\end{array}$ & $\ldots$ & $\begin{array}{l}-0.45^{8} \\
(3.001)^{*}\end{array}$ \\
\hline $\log \left(T P_{-} O M A N\right)$ & $\cdots$ & $\ldots$ & $\begin{array}{l}0.145 \\
(0.476)\end{array}$ & $\begin{array}{l}-1.069 \\
(3.066)^{*}\end{array}$ & $\begin{array}{l}0.278 \\
(0.962)\end{array}$ \\
\hline $\log (D I S)$ & $\begin{array}{l}-0.746 \\
(8.331)^{*}\end{array}$ & $\begin{array}{l}-0.037 \\
(0.159)\end{array}$ & $\begin{array}{l}-0.739 \\
(8.639)^{*}\end{array}$ & $\begin{array}{l}-0.298 \\
(1.346)\end{array}$ & $\begin{array}{l}-0.241 \\
(2.009)^{* *}\end{array}$ \\
\hline$C B$ & $\begin{array}{l}3.652 \\
(17.920)^{*}\end{array}$ & $\begin{array}{l}3.880 \\
(16.500)^{*}\end{array}$ & $\begin{array}{l}3.65^{8} \\
(18.210)^{*}\end{array}$ & $\begin{array}{l}3.814 \\
(18.060)^{*}\end{array}$ & $\begin{array}{l}3.867 \\
(23.070)^{*}\end{array}$ \\
\hline$C L$ & $\begin{array}{l}-2.488 \\
(5.721)^{*}\end{array}$ & $\begin{array}{l}-1.025 \\
(1.644)^{* * *}\end{array}$ & $\begin{array}{l}-2.481 \\
(10.400)^{*}\end{array}$ & $\begin{array}{l}-1.287 \\
(2.472)^{* *}\end{array}$ & $\begin{array}{l}-1.45^{8} \\
(5.575)^{*}\end{array}$ \\
\hline $\log (P O P-I O R-A R C)$ & $\cdots$ & $\begin{array}{l}1.002 \\
(7.290)^{*}\end{array}$ & $\cdots$ & $\begin{array}{l}\text { o.839 } \\
(7.489)^{*}\end{array}$ & $\begin{array}{l}0.612 \\
(7.269)^{*}\end{array}$ \\
\hline $\log \left(G D P_{-} I O R-A R C\right)$ & $\cdots$ & $\begin{array}{l}1.327 \\
(6.165)^{*}\end{array}$ & $\cdots$ & $\begin{array}{l}0.815 \\
(4.102)^{*}\end{array}$ & $\begin{array}{l}0.787 \\
(5.718)^{*}\end{array}$ \\
\hline $\log \left(I D^{-I O R-A R C}\right)$ & $\ldots$ & $\ldots$ & $\ldots$ & $\begin{array}{l}0.311 \\
(2.539)^{* *}\end{array}$ & $\begin{array}{l}-0.026 \\
(0.307)\end{array}$ \\
\hline$N$ & 77 & 77 & 77 & 77 & 77 \\
\hline$F$-statistics & 108.9 & 64.0 & 85.9 & 70.0 & 117.4 \\
\hline Buse $R^{2}$ & 0.90 & 0.84 & 0.91 & 0.89 & 0.94 \\
\hline
\end{tabular}

Note: ${ }^{*}{ }^{* *}$, and $* *$ indicate statistical significance at the $1 \%, 5 \%$, and $10 \%$ levels, respectively. The $t$-statistics are in parentheses. (...) indicates variable not estimated. 
level (specifications 1, 2 and 5 in Table 5.5). At the same time, we find that the coefficients of the population (POP-IOR-ARC) and GDP of the IOR-ARC countries (GDP-IOR-ARC) have the expected positive signs and are statistically significant at the $1 \%$ level, respectively (specifications 2,4 and 5 in Table 5.5). These findings suggest that the population and GDP of Oman, as well as its IOR-ARC trading partner, strongly influenced the flow of imports in a positive direction.

Our results reveal that the coefficient of the real exchange rate variable $(R E R)$ is - as expected - negative across a majority of the specifications in the export model (specifications 1, 3, 4 and 5, Table 5.4), but all of these coefficients are statistically insignificant. About the import model, our results indicate that the coefficient of the real exchange rate variable $(R E R)$ has the expected negative sign and is statistically significant (specifications 1,3 and 5, Table 5.5). Our finding for the real exchange rate variable shows that Oman's imports are very sensitive to the movements in its trading partner's exchange rates as opposed to its exports.

The coefficient trade policy ( $\left.T_{-} P_{-} O M A N\right)$ is positive and statistically significant (specification 4 and 5, Table 5.4) for Oman's exports, and while this variable has the expected positive sign in the import model, it is statistically insignificant (specification 5, Table 5.5). The robust finding of the trade policy variable on the export side provides valuable insight. Oman has attempted to liberalize its trade and economic environment through appropriate trade policy interventions to boost its exports. However, the weak effect of the trade policy variable calls for more policy interventions, particularly regarding liberalizing the nonoil export sector and making it more outward-oriented.

In the export model, the coefficient distance (DIS) is positive and contrary to our a priori expectations (see Table 5.4). However, the results of our import model show that the coefficient of distance (DIS) carries the expected negative sign across all five of the specifications and is statistically significant at the $1 \%$ level in specifications 1,3 and 5 in Table 5.5. This outcome of the distance variable is consistent with the expected adverse effects, as is usually found in gravity models. Our finding regarding the distance variable actively leads to the conclusion that distance causes significant friction for Oman's imports from the IOR-ARC countries.

The variable (ID-OMAN) has the expected positive sign for its coefficient in the export model, but it is statistically insignificant. In contrast, we find that, in the IOR-ARC countries, this variable has the expected positive coefficient and is statistically significant at the $5 \%$ level (specifications 4 and 5 in Table 5.4). On the import side, Oman's infrastructure (ID-OMAN) coefficient is negative and statistically significant (specifications 3 and 5 , Table 5.5). 
However, in the IOR-ARC countries, this variable is also negative but statistically insignificant (specification 5 , Table $5 \cdot 5$ ).

Our findings for a common border $(C B)$ reveal that the coefficient has the expected positive sign and is statistically significant at the $1 \%$ level across all the specifications, for both the export and the import model (see Tables 5.4 and 5.5). The findings of this variable suggest that having a common border tends to increase trade.

Our findings regarding a common language $(C L)$ reveal that the coefficient has the expected positive sign and is statistically significant at the $1 \%$ level in the export model (specifications 2, 4 and 5, Table 5.4). The findings of this variable suggest that having a common language facilitates Oman's exports. On the import side, the outcomes for $C L$ reveal negative signs for its coefficient, contrary to a priori expectations.

\section{Using Alternative Estimation Technique: the Generalised Methods of Moments (GMM)}

We carry out further analysis to examine whether our results remain valid if we use a different estimation technique. Here, we re-estimated the gravity models as expressed in Equations (2) and (3) using the GMM to address potential endogeneity in the data. Further, we specify the weighting scheme, providing for additional efficiency of GMM estimation, under the assumption of the 2 SLS instrument weighting matrix. Taking into account the small $N$ dimension of the panel, we choose the one-stage Arellano-Bond differenced estimator and discard more sophisticated and informationally demanding estimators (two states or system GMM). We also carefully tested for the appropriateness of the instrumental variable candidates using the Sargan test for overidentifying restrictions. Reassuringly, the test results suggested that the selected instruments are valid and relevant.

Tables 5.6 and 5.7 presents the empirical results of the Oman-IOR-ARC export and import estimations, respectively, using the GMM method. The estimated effects are broadly consistent with the results as in Tables 5.4 and 5.5, albeit with different signs in some of the coefficients.

Table 5.6 shows that the coefficients of Oman's population ( $\left.P O P_{-} O M A N\right)$ have the expected positive signs and are statistically significant. Consistent with the findings in Table 5.4, coefficients of Oman's GDP (GDP OMAN) have the expected positive sign in the specification (1) but have negative signs in specifications (2) and (3) but are statistically insignificant. The coefficients of the population $\left(P O P_{-} I O R-A R C\right)$ and GDP of the IOR-ARC countries (GDP-IOR-ARC) have the 
expected positive signs and are statistically significant, except negatives signs for (POP-IOR-ARC) in the specification (4) and (GDP-IOR-ARC) in the specification (5) but are statistically insignificant. Despite the difference, we can still conclude that the results of the GMM method support the findings in Table 5.4

TABLE 5.6 GMM method: empirical results of the Oman-IOR-ARC export model

\begin{tabular}{|c|c|c|c|c|c|}
\hline \multirow{2}{*}{ Variables } & \multicolumn{5}{|c|}{ Regression Specifications } \\
\hline & 1 & 2 & 3 & 4 & 5 \\
\hline CONSTANT & $\begin{array}{l}-51.094 \\
(-0.818)\end{array}$ & $\begin{array}{l}-9.693 \\
(-2.491)^{* *}\end{array}$ & $\begin{array}{l}-138.907 \\
(-1.402)\end{array}$ & $\begin{array}{l}-7 \cdot 310 \\
(-1.994)^{* *}\end{array}$ & $\begin{array}{l}-220.264 \\
(-2.248)^{* *}\end{array}$ \\
\hline $\log (R E R)$ & $\begin{array}{l}-3.305 \\
(1.854)^{* * *}\end{array}$ & $\begin{array}{l}4.487 \\
(1.637)\end{array}$ & $\begin{array}{l}4.049 \\
(1.285)\end{array}$ & $\begin{array}{l}4.848 \\
(1.408)\end{array}$ & $\begin{array}{l}3.427 \\
(1.038)\end{array}$ \\
\hline $\log \left(P O P_{-} O M A N\right)$ & $\begin{array}{l}12.140 \\
(2.353)^{* *}\end{array}$ & $\ldots$ & $\begin{array}{l}28.374 \\
(2.150)^{* *}\end{array}$ & $\ldots$. & $\begin{array}{l}38.371 \\
(3.353)^{*}\end{array}$ \\
\hline $\log \left(G D P_{-} O M A N\right)$ & $\begin{array}{l}7.135 \\
(1.968)^{* *}\end{array}$ & $\ldots$. & $\begin{array}{l}-11.216 \\
(-1.425)\end{array}$ & $\ldots .$. & $\begin{array}{l}-5.334 \\
(-0.786)\end{array}$ \\
\hline $\log \left(I D^{-} O M A N\right)$ & $\ldots$. & $\ldots$. & $\begin{array}{l}-0.021 \\
(1.148)\end{array}$ & $\cdots$ & $\begin{array}{l}-0.029 \\
(-1.533)\end{array}$ \\
\hline $\log \left(T P_{-}{ }^{O M A N}\right)$ & $\cdots$ & $\ldots$. & $\begin{array}{l}0.897 \\
(0.528)\end{array}$ & $\begin{array}{l}4.212 \\
(-2.750)^{*}\end{array}$ & $\begin{array}{l}-1.513 \\
(-0.988)\end{array}$ \\
\hline $\log (D I S)$ & $\begin{array}{l}0.089 \\
(0.292)\end{array}$ & $\begin{array}{l}0.370 \\
(1.658)^{* * *}\end{array}$ & $\begin{array}{l}0.125 \\
(0.4211)\end{array}$ & $\begin{array}{l}1.164 \\
(1.9 \circ 6)^{* * *}\end{array}$ & $\begin{array}{l}2.181 \\
(3.812)^{*}\end{array}$ \\
\hline$C B$ & $\begin{array}{l}0.591 \\
(2.899)^{*}\end{array}$ & $\begin{array}{l}0.603 \\
(2.766)^{*}\end{array}$ & $\begin{array}{l}0.584 \\
(2.93)^{*}\end{array}$ & $\begin{array}{l}0.253 \\
(1.855)^{* * *}\end{array}$ & $\begin{array}{l}-0.206 \\
(-0.868)\end{array}$ \\
\hline$C L$ & $\begin{array}{l}-0.116 \\
(-0.339)\end{array}$ & $\begin{array}{l}0.135 \\
(2.456)^{* *}\end{array}$ & $\begin{array}{l}0.0985 \\
(-0.296)\end{array}$ & $\begin{array}{l}0.374 \\
(1.715)^{* * *}\end{array}$ & $\begin{array}{l}0.833 \\
(1.822)^{* * *}\end{array}$ \\
\hline $\log \left(P O P_{-} I O R-A R C\right)$ & $\ldots$ & $\begin{array}{l}0.176 \\
(2.553)^{* *}\end{array}$ & $\ldots \ldots$ & $\begin{array}{l}-0.216 \\
(-0.639)\end{array}$ & $\begin{array}{l}1.029 \\
(-2.794)^{*}\end{array}$ \\
\hline $\log \left(G D P_{-} I O R-A R C\right)$ & $\cdots$ & $\begin{array}{l}0.118 \\
(1.518)^{* * *}\end{array}$ & $\cdots$ & $\begin{array}{l}0.293 \\
(2.484)^{* *}\end{array}$ & $\begin{array}{l}-0.564 \\
(-0.985)\end{array}$ \\
\hline $\log \left(I D_{-} I O R-A R C\right)$ & $\cdots$ & $\ldots$ & $\cdots$ & $\begin{array}{l}1.023 \\
(-2.507)^{* *}\end{array}$ & $\begin{array}{l}1.894 \\
(-4.538)^{*}\end{array}$ \\
\hline $\begin{array}{l}\text { Sargan test } \\
\text { ( } p \text {-value) }\end{array}$ & 0.367 & 0.585 & 0.579 & 0.527 & 0.560 \\
\hline
\end{tabular}

Note: ${ }^{* * *}$, and ${ }^{* * *}$ indicate statistical significance at the $1 \%, 5 \%$, and $10 \%$ levels, respectively. The $t$-statistics are in parentheses. (...) indicates variable not estimated. 
TABLE 5.7 GMM method: empirical results of the Oman IOR-ARC import model

\section{Regression Specifications}

\begin{tabular}{|c|c|c|c|c|c|}
\hline Variables & 1 & 2 & 3 & 4 & 5 \\
\hline CONSTANT & $\begin{array}{l}-30.507 \\
(-3.610)^{*}\end{array}$ & $\begin{array}{l}-10.360 \\
(-3.891)^{*}\end{array}$ & $\begin{array}{l}-68.523 \\
(-3.968)^{*}\end{array}$ & $\begin{array}{l}-4.877 \\
\left(-1.962^{* *}\right)\end{array}$ & $\begin{array}{l}-71.511 \\
(-5.533)^{*}\end{array}$ \\
\hline $\log (R E R)$ & $\begin{array}{l}-1.970 \\
\left(-4.15^{8}\right)^{*}\end{array}$ & $\begin{array}{l}-0.170 \\
(-0.273)\end{array}$ & $\begin{array}{l}-1.75^{0} \\
(-3.816)^{*}\end{array}$ & $\begin{array}{l}-0.674 \\
(-1.254)\end{array}$ & $\begin{array}{l}-0.947 \\
(-2.627)^{*}\end{array}$ \\
\hline $\log (P O P-O M A N)$ & $\begin{array}{l}3.270 \\
(1.214)\end{array}$ & $\ldots$ & $\begin{array}{l}10.417 \\
(2.644)^{* *}\end{array}$ & $\ldots$ & $\begin{array}{l}9.222 \\
(3.173)^{*}\end{array}$ \\
\hline $\log (G D P-O M A N)$ & $\begin{array}{l}4.278 \\
(1.941)^{* * *}\end{array}$ & $\ldots$ & $\begin{array}{l}2.370 \\
(1.72)^{* * *}\end{array}$ & $\ldots$ & $\begin{array}{l}2.202 \\
(2.283)^{* *}\end{array}$ \\
\hline $\log \left(I D^{-} O M A N\right)$ & $\ldots$ & $\ldots$ & $\begin{array}{l}-0.008 \\
(-2.938)^{*}\end{array}$ & $\ldots$ & $\begin{array}{l}-0.008 \\
(-3.872)^{*}\end{array}$ \\
\hline $\log \left(T P_{-} O M A N\right)$ & $\ldots$ & $\ldots$ & $\begin{array}{l}0.5^{01} \\
(0.967)\end{array}$ & $\begin{array}{l}-1.069 \\
(-2.310)^{* *}\end{array}$ & $\begin{array}{l}0.584 \\
(1.490)\end{array}$ \\
\hline $\log (D I S)$ & $\begin{array}{l}-0.746 \\
(-7.603)^{*}\end{array}$ & $\begin{array}{l}-0.037 \\
(-0.175)\end{array}$ & $\begin{array}{l}-0.737 \\
(-7.854)^{*}\end{array}$ & $\begin{array}{l}-0.298 \\
(-1.530)\end{array}$ & $\begin{array}{l}-0.218 \\
(-1.706)^{* * *}\end{array}$ \\
\hline$C B$ & $\begin{array}{l}1.586 \\
(19 \cdot 743)^{*}\end{array}$ & $\begin{array}{l}1.685 \\
(13.247)^{*}\end{array}$ & $\begin{array}{l}1.590 \\
(20.709)^{*}\end{array}$ & $\begin{array}{l}1.656 \\
(15.206)^{*}\end{array}$ & $\begin{array}{l}1.687 \\
(23.677)^{*}\end{array}$ \\
\hline$C L$ & $\begin{array}{l}-1.080 \\
(-9.401)^{*}\end{array}$ & $\begin{array}{l}-0.445 \\
(-2.082)^{* *}\end{array}$ & $\begin{array}{l}-1.08 \\
(-9.799)^{*}\end{array}$ & $\begin{array}{l}-0.559 \\
(-3.051)^{*}\end{array}$ & $\begin{array}{l}-0.625 \\
(-5.208)^{*}\end{array}$ \\
\hline $\log \left(P O P_{-} I O R-A R C\right)$ & $\ldots$ & $\begin{array}{l}1.002 \\
(7 \cdot 754)^{*}\end{array}$ & $\ldots$. & $\begin{array}{l}0.839 \\
(7.194)^{*}\end{array}$ & $\begin{array}{l}0.603 \\
\left(7.5^{23}\right)^{*}\end{array}$ \\
\hline $\log \left(G D P_{-} I O R-A R C\right)$ & $\ldots$ & $\begin{array}{l}1.327 \\
\left(6.75^{\circ}\right)^{*}\end{array}$ & $\ldots$ & $\begin{array}{l}0.815 \\
(4.080)^{*}\end{array}$ & $\begin{array}{l}0.793 \\
(6.073)^{*}\end{array}$ \\
\hline $\log \left(I D_{-} I O R-A R C\right)$ & $\ldots$ & $\ldots$ & $\ldots$ & $\begin{array}{l}0.311 \\
(2.580)^{* *}\end{array}$ & $\begin{array}{l}-0.055 \\
(-0.634)\end{array}$ \\
\hline $\begin{array}{l}\text { Sargan test } \\
\text { ( } p \text {-value) }\end{array}$ & 0.188 & 0.380 & 0.392 & 0.448 & 0.595 \\
\hline
\end{tabular}

Note: ${ }^{*},{ }^{* *}$, and ${ }^{* * *}$ indicate statistical significance at the $1 \%, 5 \%$, and $10 \%$ levels, respectively. The $t$-statistics are in parentheses. (...) indicates variable not estimated.

that Oman's exports are strongly influenced by its IOR-ARC trading partners' population and GDP.

Interestingly, the GMM model results support the earlier findings, as discussed in Table 5.4, where the coefficient distance (DIS) is positive in all specifications and thus contrary to expectations. Another interesting finding is 
that the coefficient $(R E R)$ has the expected negative sign, and it is statistically significant for specification (1). However, the rest of the specifications in the export model have the opposite sign but are statistically insignificant.

The findings for coefficient ( $\left.I D^{-O M A M}\right)$ have different signs in specifications (3) and (5) but are statistically insignificant. However, the results are consistent for $\left(I D^{-} I O R-A R C\right)$. The coefficient $\left(T_{-} P_{-} O M A N\right)$ is positive, as expected, and significant for specification 4, but the other specifications have the opposite sign and are insignificant. Estimation results from GMM method confirm the findings for $(C B)$ and $(C L)$ coefficients with the results obtained earlier in Table 5.4.

The results of the import model using the GMM method for all coefficients - i.e., (POP-OMAN), GDP (GDPOMAM), (POP-IOR-ARC), (GDP-IOR-ARC), $(R E R),(T P-O M A N),(D I S),\left(I D^{-} O M A N\right),\left(I D_{-}\right.$IOR-ARC), (CB) and $(C L)$ - as shown in Table 5.7 are entirely consistent with the earlier results obtained in Table 5.5 .

\section{Summary and Conclusion}

In this paper, Oman and the IOR-ARC regional trade relationship is investigated using the gravity modelling procedure. It also estimated a gravity equation to identify the core determinants of Oman's imports from the IOR-ARC group of countries. Our findings reveal that the main determinants of Oman's exports to the IOR-ARC countries are the IOR-ARC population, GDP and infrastructure; Oman's trade liberalization efforts; and a common border and language. The empirical results provide strong evidence that the core factors that determine Oman's imports from the IOR-ARC countries are the real exchange rates, distance, a common border and Oman and IOR-ARC population and GDP. Our results indicate that the application of the gravity model in this study is theoretically sound and produces some results that are consistent with the prior expectations and the theoretical predictions of the model.

The analysis reveals Oman's trade imbalances with the IOR-ARC. Oman is an open economy, with its trade contributing approximately $94 \%$ of its GDP. Since 2000, trade surpluses have been one of the hallmarks of Oman's trade performance indicators with petroleum oils and crude being the largest export commodity and generating significant export income as a result of the lucrative world oil prices. However, the recent slide in world oil prices presents a gloomy picture for the Omani economy. While a regional bloc like the IOR-ARC countries offers market access opportunities for Oman's exports, Oman's imports from the IOR-ARC countries exceed its exports, mainly related to its small export-based production, which has heavily relied on petroleum products for an extended period. The threat of a continuing slide in world oil prices means that Oman has to embark aggressively on export-led diversification in 
non-oil sectors and capitalize on the existing regional trade partnership that is gradually evolving among IOR-ARC countries.

The IOR-ARC group of countries and in particular the existing IOR-ARC trading partners of Oman certainly offer a large potential market for Oman's exports. Two of its export markets, Iran and the UAE, are quite close and offer lower levels of trade-related logistical costs and a common language. Oman's trading policy should aim at strengthening its partnerships with these two markets. An equally important element of a stronger connection is to speed up the economic diversification initiatives in the non-oil sector and quickly capture the market opportunities that exist the IOR-ARC countries. Al-Marhubi (2000) has provided empirical evidence from a sample of 91 countries over a long period (1961-88) that export diversification significantly promotes growth. The IOR-ARC countries generally have established markets, and fostering stronger trade links with them by increasing exports will undoubtedly benefit the country. Oman recognises the potential benefits of greater global integration, and its efforts to liberalize its trade sector have been ongoing since it joined the WTO. At the same time, Oman's exports to the IOR-ARC trading partners is generally constrained as a result of low levels of diversification in the non-oil sector with a generally narrow range of exportable commodities. Oman needs to embark on the diversification of the non-oil sector by increasing its investments in industries other than oil and petroleum-based products. Oman's tourism exports to IOR-ARC countries hold high potentials in light of Oman Air's growing connectivity and government investments in the tourism infrastructure. A full range of exportable products with international competitiveness will also act as a significant thrust in engaging the IOR-ARC trade partner countries in bilateral trade agreements, paving the way to greater regional integration of the Omani economy.

\section{References}

Al-Marhubi, F. (2000). Export diversification and growth: an empirical investigation, Applied Economics Letters, 7, 559-562.

Al-Marhubi, F. (2004). The determinants of governance: a cross-country analysis, Contemporary Economic Policy, 22, 394-406.

Al-Marhubi, F. (2005). Openness and governance: evidence across countries, Oxford Development Studies, 33, 453-471.

Anderson, J.E. (1979). A theoretical foundation for gravity equation, American Economic Review, 69(1), 106-116.

Anderson, J.E., van Wincoop, E. (2003). Gravity with gravitas: a solution to the border puzzle, American Economic Review, 93(1), 170-192. 
Baek, J. (2014). Exchange rate effects on Korea-U.S. bilateral trade: A new look, Research in Economics, 68(3): 214-221.

Bayar, Y. and Gavriletea, M.D. (2017). Peace, terrorism and economic growth in the Middle East and North African countries, Quality and Quantity, 52, 2373-2392.

Bergstrand, J.H. (1985). The gravity equation in international trade: some microeconomic foundations and empirical evidence, Review of Economics and Statistics, 67, $474-48$ o.

Boxell, L. (2015). K-fold cross-validation and the gravity model of bilateral trade, Atlantic Economic Journal, 43(2), 289-300.

Broda, C., Greenfield, J., Weinstein, D.E. (2017). From groundnuts to globalisation: A structural estimate of trade and growth, Research in Economics, 71(4), 759-783.

Brodzicki, T. and Uminski, S. (2018). A gravity panel data analysis of foreign trade by regions: the role of metropolises and history, Regional Studies, 52(2), 261-273.

Brooks, D.H. and Ferrarini, B. (2011). Asia's melting trade costs, The World Economy, 34(7), 1138-1147.

Brun, J-F., Carrere, C., Guillaumont, P., and de Melo, J. (2005). Has distance died? Evidence from panel gravity model, The World Bank Economic Review, 19(1), 99-120.

Central Bank of Oman. (2011 and 2019). Annual Report. Ruwi, Muscat.

Crescenzi, R. and Iammarino, S. (2017). Global investments and regional development trajectories: the missing links, Regional Studies, 51(1), 97-117.

Deardoff, A. (1995). Determinants of bilateral trade: does gravity work in a neo-classic world? National Bureau of Economic Research Working Paper 5377.

Deardorff, A. (1998). Determinants of bilateral trade: Does gravity work in a frictionless model? In the Regionalisation of the World Economy, edited by J. Frankel, pp. 7-28, Chicago: University of Chicago Press.

Egger, A. (2000). A note on the proper econometric specification of the gravity equation, Economics Letters, 66, 25-31.

Egger, P. (2008). On the role of distance on bilateral trade, The World Economy, 31(5), $653-684$.

Feng, G-F., Sui, B., Domg, M-Y., Jiang, C., and Chang, C-P. (2018). Border is better than distance? Contagious corruption in one belt and one road economic, Quality and Quantity, 52, 1909-1928.

Furtig, H. (2010). GCC-EU political cooperation: myth or reality? British Journal of Middle Eastern Studies, 31(1), 25-39.

Gani, A. and Ahmad, Nisar, (2020). Has economic growth of China and India impacted African Economic Prosperity? Atlantic Economic Journal. https://doi.org/10.1007/ s11293-020-09674-2.

Gani, A. and Al-Mawaali, N. (2013). Oman's trade and opportunities for integration with Asian economies. Economic Modelling, 31, 766-774.

Gani, A. and Scrimgeour, F. (2016). New Zealand's trade with Asia and the role of good Governance, International Review of Economics and Finance, 42, 36-53. 
Gibson, J. (2007). Is remoteness a cause of slow growth in the Pacific? A spatial econometric analysis, Pacific Economic Bulletin, 22(1), 83-101.

Gui-Diby, S.L. (2014). Impact of foreign direct investments on economic growth in Africa: Evidence from three decades of panel data analyzes, Research in Economics, $68(3), 248-256$.

Gumpert, M. (2019). Regional economic disparities under the Solow model, Quality and Quantity, retrieved from https://doi.org/10.1007/s11135-019-0o836-2.

Helpman, E. (1987). Imperfect competition and international trade: evidence from fourteen industrial countries, Journal of Japanese and International Economies, 1(1), 62.81 .

Hoekman, B. and Sekkat, K. (2010). Arab economic integration: missing links, Journal of World Trade, 44, 1273-1308.

Hye, Q.M.A., Lau, W-Y., Tourres, M-A. (2014). Does economic liberalisation promote economic growth in Pakistan? An empirical analysis, Quality and Quantity, 48, 2097-2119.

Irandoust, M. (2018). Militarism and globalisation: Is there an empirical link? Quality and Quantity, 52, 1349-1369.

Irshad, M.S., Xin, Q., Hui, Z., and Arshad, H. | Duncan Watson (Reviewing editor). (2018). An empirical analysis of Pakistan's bilateral trade and trade potential with China: A gravity model approach, Cogent Economics \& Finance, 6:1, DOI: 10.1080/23 322039.2018.1504409.

Joseph, S. (2018). Farming the desert: agriculture in the oil frontier, the case of United Arab Emirates, 1940s to 199os, British Journal of Middle Eastern Studies, 45(5), 678-694.

Keho, Y. | Miao Grace Wang (Reviewing Editor). (2017). The impact of trade openness on economic growth: The case of Cote d'Ivoire, Cogent Economics \& Finance, 5:1, DOI: $10.1080 / 23322039.2017 .1332820$.

Le, T-H and Tran-Nam, B. (2018). Trade liberalisation, financial modernisation and economic development: An empirical study of selected Asia-Pacific countries, Research in Economics, 72(2): 343-355.

Liu, X., Whalley, J., and Xin, X. (2010). Non-tradeable goods and the border effect puzzle, Economic Modelling, 27(5), 9o9-914.

Martinez-Zarzoso, I. (2003). Gravity model: an application to trade between regional blocs, Atlantic Economic Journal, 31(2), 171-187.

Omri, A. and Kahouli, B. (2014). The nexus among foreign investment, domestic capital and economic growth: Empirical evidence from the MENA region, Research in Economics, 68(3): 257-263.

Ozturk, I. (2017). The dynamic relationship between agricultural sustainability and food-energy-water poverty in a panel of selected Sub-Saharan African Countries, Energy Policy, 107, 289-299. 
Ozturk, I. and Arisoy, I. (2016). An estimation of crude oil import demand in Turkey: evidence from time-varying parameters approach, Energy Policy, 99, 174-179.

Ozturk, I., Al-Mulali, U., and Saboori, B. (2016). Investigating the environmental Kuznets curve hypothesis: the role of tourism and ecological footprint, Environmental Science and Pollution Research, 23(2), 1916-1928.

Philbin, R. (2017). People following goods: are refugee flows associated with international trade, Atlantic Economic Journal, 45(2), 267-268.

Pike, A., Rodriguez-Pose., and Tomaney, J. (2017). Shifting horizons in local and regional development, Regional Studies, 51(1), 46-57.

Rabi, U. and Mueller, C. (2017). The Gulf Arab States and Israel since 1967: from 'no negotiation' to tacit cooperation, British Journal of Middle Eastern Studies, 44(4), $576-592$.

Sen, R. (2006). "New regionalism" in Asia: a comparative analysis of emerging regional and bilateral trading agreements involving ASEAN, China and India, Journal of World Trade, 40, 553-596.

Seshadri, V.S. (2009). Evolution in India's regional trading arrangements, Journal of World Trade, 43, 903-926.

Snyder, F. (2009). China, regional trade agreements and WTO law, Journal of World Trade, 43, 1-57.

Tas, B.K.O. and Togay, S. (2012). A direct test of the endogeneity of money: implications for Gulf Cooperation Council (GCC) countries, Economic Modelling, 29(3), 577-585.

Tebaldi, E. (2011). The determinants of high technology exports: a panel data analysis, Atlantic Economic Journal, 39(4), 343-353.

Thennakoon, J. and Dissanayake, J. (2015). Trade openness, income, and role of institutions: A revisit using heterogeneous panel data models, Cogent Economics \& Finance, 3:1, DOI: 10.1080/23322039.2015.1020031.

United Nations. (2011). International Trade Statistics Yearbook. United Nations: New York.

World Bank. (2010). World Trade Indicators 2009/10. Country Trade Briefs. Washington, D.C.: World Bank. Available online at http://info.worldbank.org/etool/wtc/docs/ pman_brief.pdf.

World Bank. (2019). World Development Indicators, Washington, D.C.: World Bank. Available online at https://databank.worldbank.org/source/world-development -indicators.

World Bank. (2012). Doing Business 2012. The World Bank. Washington, D.C.

World Economic Forum. (2019). The Global Competitiveness Report, Geneva. Retrieved on 8 October 2020 from: http://www3.weforum.org/docs/WEF_The GlobalCompetitivenessReport2o19.pdf.

World Trade Organization. (May 8, 2008). Trade Policy Review - Oman. wTo, Geneva. 